\title{
Cervical cancer situation in Malaysia: A systematic literature review
}

\author{
Wan AzANi MUSTAFA ${ }^{1,2, *}$; Afiqah HALIM²; Mohd Wafi NASRUDIN ${ }^{2} ;$ Khairul Shakir Ab RAHMAN $^{3}$ \\ 1 Advanced Computing Engineering (AdvComp), Centre of Excellence (CoE), Universiti Malaysia Perlis (UniMAP), Pauh Putra Campus, Arau, Perlis, 02600, \\ Malaysia \\ 2 Faculty of Electrical Engineering Technology, UniCITI Alam Campus, Universiti Malaysia Perlis, Padang Besar, Perlis, 02100, Malaysia \\ 3 Department of Pathology, Hospital Tuanku Fauziah, Kangar, Perlis, 02000, Malaysia
}

Key words: Cervical, Cancer, Malaysia, Review, SLR

\begin{abstract}
Cervix cancer is one of Malaysia's most significant cancers for women (around 12.9\%, with an age-standardised incidence rate of 19.7 per 100,000). It was higher than other Asian, West, and even worldwide nations. The National Strategic Plan for Cancer Control Program 2016-2020 (Health Ministry) was presented to minimize cancer and mortality. The high incidence of cervical cancer in Malaysia is mainly due to women's insufficient knowledge about its prevention and importance. Compared with traditional literature reviews, the systemic analysis provides many advantages. A clearer review process, a more prominent field of study, and essential priorities that can manage research bias can all help to enhance these reviews. However, better integration, cooperation, and coordination between government and private sector as well as NGOs and professional organisations are essential for optimal cancer control and treatment across the country.
\end{abstract}

\section{Introduction}

Cancer is one of the world's leading causes of disease and death. An estimated 14,1 million new cases and 8,2 million deaths arRe recorded annually by the World Health Organization (WHO) (WHO, 2020). Due to the rise in elderly populations and unhealthy lifestyles, the incidence is expected to increase. According to the WHO, immediate action is required to improve early detection, screening, and cancer diagnosis to dramatically boost cancer patients' survival. To increase public understanding and access to early detection, screening, and diagnosis, the theme for World Cancer Day 2019, 'I Am and I Will,' seeks to promote and facilitate efforts from people, the health sector, and governments (WHO, 2019). Efforts to raise awareness of cancer will alter these habits by highlighting the value of early diagnosis and promoting early assistance in the culturally acceptable search. Malaysia is undergoing an epidemiological transformation, like most developed and advanced developing countries, where lifestyle-related

\footnotetext{
*Address correspondence to: Wan Azani Mustafa, wanazani@unimap.edu.my

Received: 29 May 2021; Accepted: 13 August 2021
}

diseases, especially cardiovascular diseases and cancers, have increasingly become more prevalent.

In terms of absolute figures, the trend of malignant neoplasms has risen and remains one of the five major causes of national mortality in the last 20 years. Cancer accounted for $13.6 \%$ of all deaths in the Ministry of Health hospitals in 2015 , compared with $8.9 \%$ in 1996 . Generally, one-third of cancers can be cured. Another third can be successfully treated with early diagnosis and treatment, while pain management and palliative care can improve the quality of life for the remaining third with more advanced diseases (Ministry of Health Malaysia, 2007, 2011; Adilah, 2018).

The third most prevalent female cancer in Malaysia is cervix cancer. The Malaysian National Registry of Cancer found that the most common cancers of breast, colon, ovary, leukaemia, and lungs have been recorded in Malaysian women (descending order). Cervical cancer deaths in young women are uncommon, but the incidence of cervical cancer has risen from 30 years old to 60-69 years old. The women aged $40-59$ years accounted for half (54.7\%) of the incidents.

Incidence rates among Chinese women were generally higher $(28,8 / 100,000)$ followed by the Chinese $(22,4 /$ $100,000)$, while the Malays $(10,5 / 100,000)$ were the lowest (Omar et al., 2010; Malaysia of Health National Cancer Registry, 2011; Zainal Ariffin and Nor Saleha, 2011). 
Malaysia's Ministry of Health estimated between 2000 and 3000 hospital admissions of cervical cancer cases per year. Moreover, the death rate is 5.6 per 100,000 for cervical cancer (Cervical Cancer Incidence and Mortality Rates 2011). Malaysia is over doubly higher than the Netherlands, the United Kingdom, and Finland in term of cervical cancer. The death rate was not decreased to an acceptable amount, even with the advent of screening programs and cervical cancer immunisation. Cervical cancer causes an immense economic burden. The management of cervical cancer in Malaysia (from prevention to the management of invasive diseases) costs about RM312 million (USD 76 million) a year. Managing invasive cancer cases accounts for a large proportion (67\%). For the 2012-2016 period, a total of 3,981 cases of cervix uterine cancer were diagnosed, compared with 4,352 cases in the 2007-2011 survey. Over the five years, the incidence rate decreased from 7.6 to 6.2 per 100,000 people. The chance for a lifetime was 1 in 144 . Fig. 1 also depicts the instances based on ethnicity. The Malay had the most cases (49\%) compared to the Chinese (42\%) and the Indians (9\%) based on age-standardised rate (ASR) per 100,000 population. Chinese, led by Indians and Malays, had higher incidence rates. The lifetime chance was 1 in 129 for Chinese, 1 in 157 for Indians and 1 in 194 for Malays. The age-specific incidence rate pattern was similar in both studies, with the highest incidence at 50-65 years of age.

In 2,771 cases, the staging was reported for (70\%). At the late stages (III \& IV), which was marginally higher than the previous study, $41 \%$ of these were found (40.3\%). Meanwhile, at Stages I and II, 59 per cent were found (Ministry of Health Malaysia, 2017; National Cancer Institute, 2019). Tab. 1 displays the incidence distribution in Malaysia from 2012 to 2016, with Sarawak accounting for 575 cases and Sabah reaching 570 cases. The lowest is 10 cases from W.P. Labuan.

\section{TABLE 1}

Incidence summary table for cervix cancer sites by state and ethnicity in Malaysia 2012-2016

\begin{tabular}{ll}
\hline State & Total \\
\hline Sarawak & 575 \\
Sabah & 570 \\
Johor & 501 \\
Selangor & 447 \\
Perak & 310 \\
Penang & 307 \\
Kedah & 227 \\
Pahang & 208 \\
WPKL\&P & 179 \\
Kelantan & 178 \\
N. Sembilan & 176 \\
Melaka & 142 \\
Terengganu & 100 \\
Perlis & 51 \\
W.P. Labuan & 10 \\
\hline
\end{tabular}

The current study is important because there is a scarcity of research that provides a comprehensive picture of the state of cervical cancer in Malaysia. Moreover, existing systematic review articles on the subject fail to provide detailed information on the review procedures used. This includes keyword identification, article screening, and article eligibility. Furthermore, prospective researchers were unable to reconstruct the inquiry, authorise the interpretation, or evaluate the breadth of data due to this situation. In addition, this study is important because it provides researchers an understanding of the peer literature review that help researchers achieve a better understanding of possible cancer issues requiring academic and government attention. The current systemic analysis was developed to answer the main research question: How critical is cervical cancer in Malaysia? The investigation's main focus was on people's perceptions of cancer, including their awareness. More specifically, since this population is expected to be significantly affected by the impacts of vaccination programmes due to their strong dependence on natural stability, special attention was paid to education and awareness. Aside from that, this section addresses the need for a thorough analysis of the cervical cancer situation.

In contrast, the following section describes the procedure used to respond to the research question raised by the current report. The third section then performs a systematic analysis and synthesis of the scientific literature to identify, select, and analyse necessary research on Malaysia's cervical cancer situation. Finally, the section addresses the steps that must be taken, emphasising potential scholars about the problems presented.

\section{Materials and Methods}

A large number of current studies related to systematic assessments have been undertaken around the globe. However, within the context of cervical cancer overview, only a small number of studies in Malaysia were carried out (Puteh et al., 2008; Othman and Rebolj, 2009; Zaridah, 2014; Muhamad et al., 2015). This section addresses the need for a systemic analysis of the cervical cancer situation in Malaysia. In contrast, the following section presents the method used to find answers to the research formulated by the current research. This review will be broken down into three sections: (1) screening and vaccination programs, (2) knowledge and awareness, and (3) challenges and problems. Besides, the sub-objective is to explore the detailed incidence rate and how it is solved. The detailed measures and approaches to improve the understanding of HPV and cervical cancer in Malaysia were also studied and explained. Next, this section systematically reviews and synthesises scientific literature to distinguish, select, and analyse important cervical cancer research. Lastly, the last addresses what action should be taken concerning the posed problems by reflecting upon potential scholars. The pre-recording systematic reviews and meta-analysis (PRISMA) approach is applied in this analysis, a published standard for conducting a systematic literature review. Publication guidelines are generally necessary for guiding writers to assess and review the accuracy and rigour of a review with relevant and 


\section{RACE}

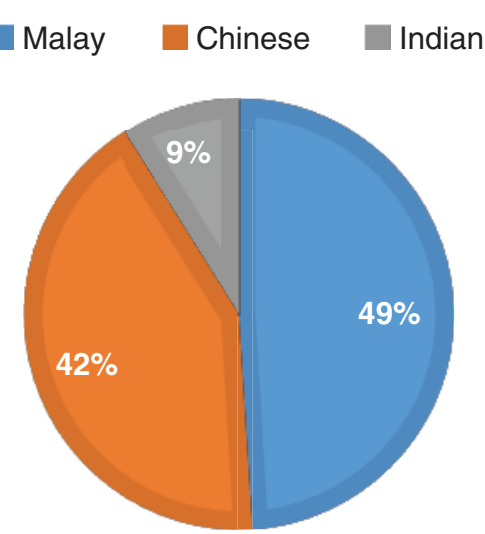

FIGURE 1. The cervical cancer case report based on race in Malaysia from 2012 to 2016.

necessary details. PRISMA also highlights the randomised studies evaluations survey, which can be a key factor in systematic analysis reports for other study forms (Moher et al., 2009) (Fig. 2).

In terms of tools, two key databases, Scopus and PubMed, were used to evaluate the methodology of this research in light of their robust nature. It covered several studies, including cancer studies. However, like Scopus and PubMed, no database is perfect and detailed (Schmidt et al., 2016; Kokol and Vošner, 2018; Yeung, 2019). In addition, this section provides an overview of the four significant sub-sections: identification, screening, eligibility, and data abstraction.

\section{Identification}

In choosing several appropriate papers for this report, the systematic review process consists of three main phases. The first step is keyword recognition and the quest for linked, similar terms based on the thesaurus, dictionaries, encyclopedia, and previous studies. Accordingly, after all the relevant keywords were decided, search strings on Scopus and PubMed (Tab. 2) database have been created. In the first step of the systematic review process, the present research work successfully retrieved 74 papers from both databases.

\section{Screening}

Duplicated papers should be excluded during the first step of screening. The first phase omitted 26 articles, while the second

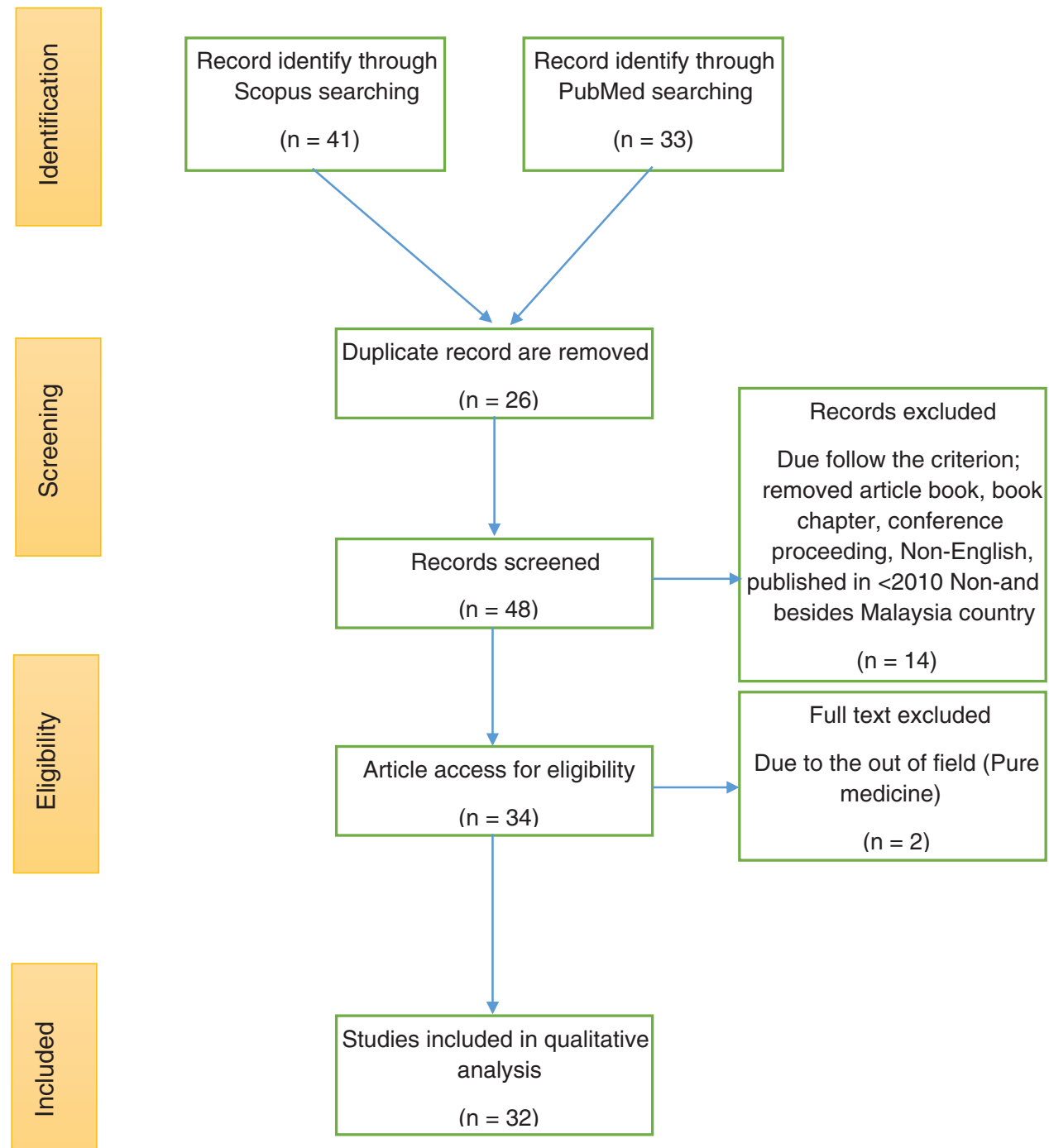

FIGURE 2. Flow diagram of the proposed searching study (Moher et al., 2009). 
TABLE 2

The search string

\begin{tabular}{cl}
\hline Scopus & TITLE (cervical AND Malaysia) AND ( LIMIT-TO \\
& (PUBYEAR, 2020) OR LIMIT-TO (PUBYEAR, 2019) \\
& OR LIMIT-TO (PUBYEAR, 2018) OR LIMIT-TO \\
& (PUBYEAR, 2017) OR LIMIT-TO (PUBYEAR, 2016) \\
& OR LIMIT-TO (PUBYEAR, 2015) OR LIMIT-TO \\
& (PUBYEAR, 2014) OR LIMIT-TO (PUBYEAR, 2013) \\
& OR LIMIT-TO (PUBYEAR, 2011) OR LIMIT-TO \\
& (PUBYEAR, 2010)) AND (EXCLUDE (DOCTYPE, \\
& "chi")) \\
PubMed (cervical”[Title] AND “malaysia”[Title]) AND (y_10 & \\
& [Filter])
\end{tabular}

phase screened 48 articles based on several inclusion-andexclusion criteria developed by researchers. Literature (research articles) was the first criterion because it is the primary source of practical information. It also includes the exclusion from the current study of publications in the form of systematic review, review, meta-analysis, meta-synthesis, book series, books, chapters, and conference proceedings. Furthermore, the review concentrated exclusively on papers written in English. It is essential to note that the schedule was chosen for a ten-year duration (2010-2020). Otherwise, only studies carried out in Malaysia's territory have been selected to conform to the analysis objective. In all, 14 publications based on specific parameters were excluded.

\section{Eligibility}

For the third step, known as eligibility, a total of 34 articles have been prepared. All articles' titles and key content were thoroughly reviewed at this stage to ensure that the inclusion requirements were fulfilled and fit into the present study with the current research aims. Therefore, two reports were omitted because they were not pure science articles based on empirical evidence. Finally, 32 articles are available for review (Tab. 3).

\section{Data Abstraction and Analysis}

An integrative analysis was performed in this study, which was one of the examination techniques used to analyse and synthesise different research designs (qualitative, quantitative, and mixed methods). Expert research centered

TABLE 3

The selection criterion is searching

\begin{tabular}{|c|c|c|}
\hline Criterion & Inclusion & Exclusion \\
\hline Language & English & Non-English \\
\hline Time line & $\begin{array}{l}\text { Between } \\
\text { 2010-2020 }\end{array}$ & $<2010$ \\
\hline $\begin{array}{l}\text { Literature } \\
\text { type }\end{array}$ & $\begin{array}{l}\text { Journal (only } \\
\text { research articles) }\end{array}$ & $\begin{array}{l}\text { Journal (book chapter, } \\
\text { conference proceeding) }\end{array}$ \\
\hline Countries & Malaysia only & Besides Malaysia \\
\hline
\end{tabular}

on developing appropriate topics and sub-topics. The first step in the development of the theme was the data collection phase. The authors have carefully reviewed a group of 32 papers for statements or information addressing questions from this current research. In the second step, the authors and expert then analyse the cervical cancer situation in the country, determine and form meaningful groups. The three main themes that emerged from the approach are awareness and understanding, screening and vaccine programme, and challenges. The authors resumed each developed theme from here, including any themes, concepts, or ideas having any relationship. Within the framework of this study, the corresponding author worked with other coauthors to establish themes based on the findings. Here, a $\log$ was maintained during the data analysis process to document any analysis, opinions, puzzles, or other ideas relevant to the data interpretation.

The authors also compared the findings to resolve any discrepancies in the theme creation process. Note that if any inconsistencies on the themes arose, the authors addresses them with one another. Finally, the developed themes were tweaked to ensure their consistency. To ensure the validity of the problems, the examinations were performed by two experts, one specialising in oncology and the other in biomedical science. The expert review phase helped ensure each sub-theme's clarity, importance, and adequacy by establishing domain validity. Adjustments based on the discretion of the author based on feedback and comments by experts have been made.

\section{Result and Finding}

Cancer is one of Malaysia's most significant health issues. As public health concerns the growth and success of this region, the disease has become increasingly significant. Based on the searching technique, 32 articles were extracted and analysed.

All articles were categorised based on three main themes, which are knowledge and awareness (10 articles), screening and vaccination program (11 articles), and challenge and problem (11 articles) (Tab. 4).

\section{Knowledge and Awareness}

The program for HPV immunisation has been promising, but vaccination performance remains poor (Zaridah and Ukm, 2014). To increase the understanding and tracking of the disease, public education programs are critical-the program aimed to alleviate the burden of sickness. Girls are vaccinated via the new school health programme to achieve this purpose. For school students, parental education impacts the HPV vaccine. To improve the understanding of HPV and cervical cancer in Malaysia, public health services are required. Withdrawal signs, implications, price, and effectiveness are the greatest obstacles to researching vaccines and pap smears. Because of the vaccination coverage, safety, health advice, and parents, most participants can take the vaccine.

The participants were supportive concerning HPV vaccination and cervical cancer screening. Malaysian women are also unfamiliar with HPV and cervical cancer. Measures 
TABLE 4

The research article finding based on the proposed searching criterion

\begin{tabular}{|c|c|c|c|c|c|c|}
\hline No. & Author & Journal & Title & Scopus & PubMed & Remarks \\
\hline 1 & $\begin{array}{l}\text { Nahrawi } \\
\text { et al. }\end{array}$ & (2020) Sains Malaysiana & $\begin{array}{l}\text { Knowledge of human papillomavirus (HPV) } \\
\text { and cervical cancer among Malaysia residents: } \\
\text { A review }\end{array}$ & / & & $\begin{array}{l}\text { Knowledge and } \\
\text { Awareness }\end{array}$ \\
\hline 2 & Romli et al. & $\begin{array}{l}\text { (2020) Asian Pacific Journal of } \\
\text { Cancer Prevention }\end{array}$ & $\begin{array}{l}\text { Effectiveness of a health education program to } \\
\text { improve knowledge and attitude towards } \\
\text { cervical cancer and pap smear: A controlled } \\
\text { community trial in Malaysia }\end{array}$ & / & I & $\begin{array}{l}\text { Screening and } \\
\text { Vaccination } \\
\text { Program }\end{array}$ \\
\hline 3 & $\begin{array}{l}\text { Tusimin } \\
\text { et al. }\end{array}$ & (2019) BMC Public Health & $\begin{array}{l}\text { Socio-demographic determinants of } \\
\text { knowledge and attitude in the primary } \\
\text { prevention of cervical cancer among University } \\
\text { Tunku Abdul Rahman (UTAR) students in } \\
\text { Malaysia: Preliminary study of HPV } \\
\text { vaccination }\end{array}$ & / & I & $\begin{array}{l}\text { Screening and } \\
\text { Vaccination } \\
\text { Program }\end{array}$ \\
\hline 4 & $\begin{array}{l}\text { Faten } \\
\text { Nurjihan } \\
\text { et al. }\end{array}$ & $\begin{array}{l}\text { (2019) Indian Journal of Medical } \\
\text { and Paediatric Oncology }\end{array}$ & $\begin{array}{l}\text { The knowledge, attitude, and practice } \\
\text { regarding pap smear, cervical cancer, and } \\
\text { human papillomavirus among women } \\
\text { attending a mother and child health clinic in } \\
\text { Kuantan, Malaysia }\end{array}$ & / & & $\begin{array}{l}\text { Knowledge and } \\
\text { Awareness }\end{array}$ \\
\hline 5 & Romli et al. & $\begin{array}{l}\text { (2019) Medical Journal of } \\
\text { Malaysia }\end{array}$ & $\begin{array}{l}\text { Cervical cancer and pap smear screening: } \\
\text { Knowledge, attitude and practice among } \\
\text { working women in the northern state of } \\
\text { Malaysia }\end{array}$ & / & I & $\begin{array}{l}\text { Knowledge and } \\
\text { Awareness }\end{array}$ \\
\hline 6 & $\begin{array}{l}\text { Nwabichie } \\
\text { et al. }\end{array}$ & $\begin{array}{l}\text { (2018) Asian Pacific Journal of } \\
\text { Cancer Prevention }\end{array}$ & $\begin{array}{l}\text { Factors affecting uptake of cervical cancer } \\
\text { screening among African Women in Klang } \\
\text { Valley, Malaysia }\end{array}$ & / & I & $\begin{array}{l}\text { Challenge and } \\
\text { problem }\end{array}$ \\
\hline 7 & Malhi et al. & $\begin{array}{l}\text { (2018) Journal of Global Pharma } \\
\text { Technology }\end{array}$ & $\begin{array}{l}\text { Knowledge on cervical cancer prevention and } \\
\text { attitude towards pap smear and HPV } \\
\text { vaccination among women attending a health } \\
\text { clinic in IPOH, Malaysia }\end{array}$ & I & & $\begin{array}{l}\text { Knowledge and } \\
\text { Awareness }\end{array}$ \\
\hline 8 & $\begin{array}{l}\text { Maharajan } \\
\text { et al. }\end{array}$ & $\begin{array}{l}\text { (2017) Journal of Cancer } \\
\text { Education }\end{array}$ & $\begin{array}{l}\text { Cervical Cancer Prevention in Malaysia: } \\
\text { Knowledge and Attitude of Undergraduate } \\
\text { Pharmacy Students Towards Human } \\
\text { Papillomavirus Infection, Screening and } \\
\text { Vaccination in Malaysia }\end{array}$ & / & I & $\begin{array}{l}\text { Screening and } \\
\text { Vaccination } \\
\text { Program }\end{array}$ \\
\hline 9 & $\begin{array}{l}\text { Maharajan } \\
\text { et al. }\end{array}$ & $\begin{array}{l}\text { (2015) Asian Pacific Journal of } \\
\text { Cancer Prevention }\end{array}$ & $\begin{array}{l}\text { Knowledge of human papillomavirus infection, } \\
\text { cervical cancer and willingness to pay for } \\
\text { cervical cancer vaccination among ethnically } \\
\text { diverse medical students in Malaysia }\end{array}$ & l & I & $\begin{array}{l}\text { Knowledge and } \\
\text { Awareness }\end{array}$ \\
\hline 10 & $\begin{array}{l}\text { Muhamad } \\
\text { et al. }\end{array}$ & $\begin{array}{l}\text { (2015) Asian Pacific Journal of } \\
\text { Cancer Prevention }\end{array}$ & $\begin{array}{l}\text { Survival rates of cervical cancer patients in } \\
\text { Malaysia }\end{array}$ & l & I & $\begin{array}{l}\text { Challenge and } \\
\text { problem }\end{array}$ \\
\hline 11 & $\begin{array}{l}\text { Sheikh et } \\
\text { al. }\end{array}$ & $\begin{array}{l}\text { (2015) International Journal of } \\
\text { Pharmaceutical Sciences Review } \\
\text { and Research }\end{array}$ & $\begin{array}{l}\text { A pilot survey of awareness and knowledge of } \\
\text { human papillomavirus (HPV), cervical cancer } \\
\text { and HPV vaccine among men and women } \\
\text { attending for HPV vaccination in Terengganu, } \\
\text { Malaysia }\end{array}$ & I & & $\begin{array}{l}\text { Knowledge and } \\
\text { Awareness }\end{array}$ \\
\hline 12 & Latiff et al. & $\begin{array}{l}\text { (2015) Asian Pacific Journal of } \\
\text { Cancer Prevention }\end{array}$ & $\begin{array}{l}\text { Assessment of the reliability of a novel self- } \\
\text { sampling device for performing cervical } \\
\text { sampling in Malaysia }\end{array}$ & I & I & $\begin{array}{l}\text { Challenge and } \\
\text { problem }\end{array}$ \\
\hline 13 & Zaridah & $\begin{array}{l}\text { (2014) Medical Journal of } \\
\text { Malaysia }\end{array}$ & $\begin{array}{l}\text { A review of cervical cancer research in } \\
\text { Malaysia }\end{array}$ & l & I & $\begin{array}{l}\text { Knowledge and } \\
\text { Awareness }\end{array}$ \\
\hline 14 & Raub et al. & $\begin{array}{l}\text { (2014) Asian Pacific Journal of } \\
\text { Cancer Prevention, }\end{array}$ & $\begin{array}{l}\text { Distribution of HPV genotypes in cervical } \\
\text { cancer in multi-ethnic Malaysia }\end{array}$ & l & I & $\begin{array}{l}\text { Challenge and } \\
\text { problem }\end{array}$ \\
\hline 15 & Razak et al. & $\begin{array}{l}\text { (2013) International Medical } \\
\text { Journal }\end{array}$ & $\begin{array}{l}\text { Survival analysis of cervical cancer patients } \\
\text { treated in hospital Universiti sains Malaysia }\end{array}$ & / & & $\begin{array}{l}\text { Challenge and } \\
\text { problem }\end{array}$ \\
\hline
\end{tabular}

(Continued) 
Table 4 (continued).

\begin{tabular}{|c|c|c|c|c|c|c|}
\hline No. & Author & Journal & Title & Scopus & PubMed & Remarks \\
\hline 16 & $\begin{array}{l}\text { Osman } \\
\text { et al. }\end{array}$ & $\begin{array}{l}\text { (2013) World Journal of Medical } \\
\text { Sciences }\end{array}$ & $\begin{array}{l}\text { Knowledge and awareness of cervical cancer } \\
\text { screening among Iraqi immigrant women } \\
\text { living in Malaysia }\end{array}$ & I & & $\begin{array}{l}\text { Knowledge and } \\
\text { Awareness }\end{array}$ \\
\hline 17 & $\begin{array}{l}\text { Gan, } \\
\text { Dahlui }\end{array}$ & (2013) Singapore Medical Journal & $\begin{array}{l}\text { Cervical screening uptake and its predictors } \\
\text { among rural women in Malaysia }\end{array}$ & l & l & $\begin{array}{l}\text { Screening and } \\
\text { Vaccination } \\
\text { Program }\end{array}$ \\
\hline 18 & $\begin{array}{l}\text { Rashid, } \\
\text { Dahlui }\end{array}$ & $\begin{array}{l}\text { (2013) Asian Pacific Journal of } \\
\text { Cancer Prevention }\end{array}$ & $\begin{array}{l}\text { Study protocol for the most effective recall } \\
\text { method in a cervical cancer screening program } \\
\text { in Klang, Malaysia }\end{array}$ & I & l & $\begin{array}{l}\text { Screening and } \\
\text { Vaccination } \\
\text { Program }\end{array}$ \\
\hline 19 & Juhan et al. & $\begin{array}{l}\text { (2013) Iranian Journal of Public } \\
\text { Health }\end{array}$ & $\begin{array}{l}\text { Survey of patients with cervical cancer in } \\
\text { Hospital Universiti Sains Malaysia: Survival } \\
\text { data analysis with time-dependent covariate }\end{array}$ & l & l & $\begin{array}{l}\text { Knowledge and } \\
\text { Awareness }\end{array}$ \\
\hline 20 & $\begin{array}{l}\text { Abdullah } \\
\text { et al. }\end{array}$ & $\begin{array}{l}\text { (2013) BioMed Research } \\
\text { International }\end{array}$ & $\begin{array}{l}\text { Evaluation of a worksite cervical screening } \\
\text { initiative to increase Pap Smear uptake in } \\
\text { Malaysia: A cluster randomised controlled trial }\end{array}$ & I & l & $\begin{array}{l}\text { Challenge and } \\
\text { problem }\end{array}$ \\
\hline 21 & $\begin{array}{l}\text { Rashid } \\
\text { et al. }\end{array}$ & $\begin{array}{l}\text { (2013) Asian Pacific Journal of } \\
\text { Cancer Prevention }\end{array}$ & $\begin{array}{l}\text { Adapting the Australian system: Is an } \\
\text { organised screening program feasible in } \\
\text { Malaysia?-An overview of the cervical cancer } \\
\text { screening in both countries }\end{array}$ & l & l & $\begin{array}{l}\text { Screening and } \\
\text { Vaccination } \\
\text { Program }\end{array}$ \\
\hline 22 & Razak et al. & $\begin{array}{l}\text { (2013) Asian Pacific Journal of } \\
\text { Cancer Prevention }\end{array}$ & $\begin{array}{l}\text { Estimating the five-year survival of cervical } \\
\text { cancer patients treated in Hospital Universiti } \\
\text { Sains Malaysia }\end{array}$ & l & I & $\begin{array}{l}\text { Challenge and } \\
\text { problem }\end{array}$ \\
\hline 23 & $\begin{array}{l}\text { Rashwan } \\
\text { et al. }\end{array}$ & $\begin{array}{l}\text { (2011) Asian Pacific Journal of } \\
\text { Cancer Prevention }\end{array}$ & $\begin{array}{l}\text { Knowledge of cervical cancer and acceptance of } \\
\text { HPV vaccination among secondary school } \\
\text { students in Sarawak, Malaysia }\end{array}$ & 1 & & $\begin{array}{l}\text { Screening and } \\
\text { Vaccination } \\
\text { Program }\end{array}$ \\
\hline 24 & Khoo et al. & $\begin{array}{l}\text { (2011) Asian Pacific Journal of } \\
\text { Cancer Prevention }\end{array}$ & $\begin{array}{l}\text { Awareness of cervical cancer and HPV } \\
\text { vaccination and its affordability among rural } \\
\text { folks in Penang Malaysia }\end{array}$ & I & & $\begin{array}{l}\text { Knowledge and } \\
\text { Awareness }\end{array}$ \\
\hline 25 & Dunn et al. & $\begin{array}{l}\text { (2010) Social Science and } \\
\text { Medicine }\end{array}$ & $\begin{array}{l}\text { Cervical cancer screening in Malaysia: Are } \\
\text { targeted interventions necessary? }\end{array}$ & l & & $\begin{array}{l}\text { Screening and } \\
\text { Vaccination } \\
\text { Program }\end{array}$ \\
\hline 26 & $\begin{array}{l}\text { Chong et } \\
\text { al. }\end{array}$ & $\begin{array}{l}\text { (2010) Asian Pacific Journal of } \\
\text { Cancer Prevention }\end{array}$ & $\begin{array}{l}\text { High prevalence of human papillomavirus } \\
\text { DNA detected in cervical swabs from women } \\
\text { in Southern Selangor, Malaysia }\end{array}$ & l & & $\begin{array}{l}\text { Screening and } \\
\text { Vaccination } \\
\text { Program }\end{array}$ \\
\hline 27 & $\begin{array}{l}\text { Aljunid } \\
\text { et al. }\end{array}$ & $\begin{array}{l}\text { (2010) Asian Pacific Journal of } \\
\text { Cancer Prevention }\end{array}$ & $\begin{array}{l}\text { The burden of disease associated with cervical } \\
\text { cancer in Malaysia and potential costs and } \\
\text { consequences of HPV vaccination }\end{array}$ & 1 & & $\begin{array}{l}\text { Challenge and } \\
\text { problem }\end{array}$ \\
\hline 28 & $\begin{array}{l}\text { Abdullah, } \\
\mathrm{Su}\end{array}$ & $\begin{array}{l}\text { (2010) Asian Pacific Journal of } \\
\text { Cancer Prevention }\end{array}$ & $\begin{array}{l}\text { Enhancement of the cervical cancer screening } \\
\text { program in Malaysia: A qualitative study }\end{array}$ & l & & $\begin{array}{l}\text { Screening and } \\
\text { Vaccination } \\
\text { Program }\end{array}$ \\
\hline 29 & $\begin{array}{l}\text { Al-Naggar } \\
\text { et al. }\end{array}$ & $\begin{array}{l}\text { (2010) Asian Pacific Journal of } \\
\text { Cancer Prevention }\end{array}$ & $\begin{array}{l}\text { Knowledge and barriers towards cervical } \\
\text { cancer screening among young women in } \\
\text { Malaysia }\end{array}$ & l & & $\begin{array}{l}\text { Challenge and } \\
\text { problem }\end{array}$ \\
\hline 30 & $\begin{array}{l}\text { Ezat, } \\
\text { Aljunid }\end{array}$ & $\begin{array}{l}\text { (2010) Asian Pacific Journal of } \\
\text { Cancer Prevention }\end{array}$ & $\begin{array}{l}\text { Comparative cost-effectiveness of HPV } \\
\text { vaccines in the prevention of cervical cancer in } \\
\text { Malaysia }\end{array}$ & / & & $\begin{array}{l}\text { Challenge and } \\
\text { problem }\end{array}$ \\
\hline 31 & $\begin{array}{l}\text { Ezat, } \\
\text { Aljunid }\end{array}$ & $\begin{array}{l}\text { (2010) Asian Pacific Journal of } \\
\text { Cancer Prevention }\end{array}$ & $\begin{array}{l}\text { Cost-effectiveness of HPV vaccination in the } \\
\text { prevention of cervical cancer in Malaysia }\end{array}$ & l & & $\begin{array}{l}\text { Challenge and } \\
\text { problem }\end{array}$ \\
\hline 32 & Seng et al. & $\begin{array}{l}\text { (2018) International Journal of } \\
\text { Health Sciences }\end{array}$ & $\begin{array}{l}\text { Awareness of cervical cancer among women in } \\
\text { Malaysia }\end{array}$ & & l & $\begin{array}{l}\text { Knowledge and } \\
\text { Awareness }\end{array}$ \\
\hline
\end{tabular}

ought to be taken to increase awareness of cervical cancer. In minimising cervical cancer cases, the integrated HPV and Pap smear screening programs are cost-effective (Nahrawi et al.,
2020). A high degree of understanding of cervical cancer and its vaccination was shown by $90 \%$ of Malaysian students. Eighty-eight (88\%) said the HPV vaccine would 
prevent cervical cancer, while $81.5 \%$ said they would warn the public about the HPV vaccine. The distribution in Malaysia of the HPV vaccine for long periods (over four years) and medical students' clinical training are the main reasons they have a greater awareness about HPV infection and cervical cancer vaccination (Maharajan et al., 2015). The study explains the disparities and inequalities in HPV-related vaccine knowledge, actions, and willingness to pay for HPV vaccines.

Chinese, Malaysian, and Indian medical students are more conscious of HPV infection, Pap smear testing, and vaccination against HPV. Medical students were pleased to suggest HPV immunisation to the population. Another study was conducted in Ipoh, Malaysia, examining the effect of awareness-raising prevention initiatives and cervical cancer attitudes on pap smear and HPV vaccinations (Malhi et al., 2018). The majority of respondents were between 26 and 45 years old (44\%) and were well-known about cervical cancer, Pap smears, and HPV. Most respondents expressed a positive approach to Pap smear and cervical vaccination. The levels of knowledge in the different age groups were significantly different.

In the management of multi-ethnic groups, cultural differences can pose additional barriers. High-level planning and therapy skills are required for medical students, where the curriculum and clinical experience assist this culture of medical students. The prescribers are committed to educating their patients on issues like HPV. Educational and occupational levels significantly shaped women's attitudes towards cervical cancer, Pap smear, and HPV vaccine. Compared to younger and older women, Malay ethnic groups had better awareness of cervical cancer and a greater understanding of the disease than other races and middleaged women (Razak et al., 2013). The impression of susceptibility to cervical cancer can influence screening attitudes. A lower survival prognosis was seen in Stage III and IV patients than in Stages I and II patients.

To conclude, age is closely linked to cervical prevention. Step III \& IV diagnosed patients were found to have the most significant risk of death. In Terengganu, Malaysia, a pilot survey of Human Papillomavirus (HPV), cervical cancer, HPV vaccine awareness, and information was conducted. This research was performed to determine the prevalence of HPV vaccination for cervical cancer and its durability among rural Malaysian people. Public education on the infection can help the disease to be contained. Eighty (80\%) of sexually active women aged 50 years and older are estimated to be vulnerable to HPV (Sheikh et al., 2015). Both socio-demographic populations are potentially and equally affected by HPV infections. Among low-education and low-education unmarried women, it is also noted that HPV has a clear preference for specific ancestral clusters.

In Malaysia, just $10.3 \%$ (RM 32 million) of the annual Pap smear testing cost was allocated, while RM 167 million was used to treat recurrent cervical cancer. RM 150 million annually is invested by the Government of Malaysia on the National HPV Screening Program (Khoo et al., 2011). In a region, along with its screening program, an HPV immunisation program should be implemented. While they are already vaccinated, it should also be recommended that the community conduct routine Pap screening. The disease education scheme can help to prevent the disease. The cost of HPV vaccines is a significant impediment to vaccination coverage. The research aims to assess and evaluate women's perception, expertise, awareness, and attitudes to the disease in Malaysia today. Women are only aware that cervical cancer risk variables are, for example, having multiple sex experiences and STDs. They also recognise that CC can be treated and diagnosed by routine Pap Smear and surgery (Seng et al., 2018). Health education, barrier-specific guidance and outreach, and community-based services should be sufficient to give cervical screening a chance and increase awareness. Education for women is equal to the education of a generation and the entire nation. The study highlights significant barriers among women to Pap screening. To enhance women's awareness of pap smear, $\mathrm{CC}$, and HPV, the health organisation needs to build better methods to improve these challenges.

It is essential to develop a curriculum on Pap smear, CC, and HPV to be implemented in high schools, hospitals, and maternity clinics. Women in Malaysia should also be able to access media such as radio and television advertising. In Kedah, Malaysia, a study examined knowledge, attitudes, and practices among 210 female entrepreneurs. Around half (55.2\%) had been screened for Pap smear, while in the previous five years, $38.6 \%$ had been tested. Women entrepreneurs sponsored by Malaysia's Amanah Ikhtiar (AIM), a non-governmental microfinance organisation that provides women with capital funding, savings, and health support, were included in the study population with the primary objective of alleviating poverty. The authors conclude that women's awareness varies depending on their cultures, where most participants have never performed HPV and Pap smear (Faten Nurjihan et al., 2019).

The study compared the perception of screening for cervical cancer among Iraqi immigrant women living in Malaysia. They are the first Iraqi women living outside of Iraq to get cancer screenings. The prevalence of the disease and mortality rates are high. More awareness will help enhance understanding. Ground-breaking public access to health education modules outside health centres will educate the public and increase Pap Smear testing by women. A study found very little awareness among Iraqi immigrant women (Romli et al., 2019). Eighteen respondents aged between 18 to 61 years (mean $=36,1$ ) returned the survey question. Around $57.4 \%$ have heard of cancer, and just $13 \%$ have heard of vaccination against HPV. The effects of an abnormal cervical smear and the need to detect precancerous cervical cancer were not well understood by many women (Osman et al., 2013). Global Patterns Survey of National Health Information by the National Institute for Cancer stated that $20 \%$ of women were aware that cervical cancer could be caused by HPV. The findings emphasise the need to educate these women to comply with Malaysia's Ministry of Health requirements.

\section{Screening and Vaccination Program}

The previous section presents the knowledge and awareness about cervical cancer screening, which is very important to reduce the number of patients in the future. Thus, this section will elaborate on some of the related screening and 
vaccination programs carried out previously. For instance, Dunn and Tan (2010) investigated the determinants of Papanicolaou Smear Test (PST) screening for Cervical Cancer among women in Malaysia. The essential explanations for non-screening by different population groups are discussed in this report. The result screening behaviour, ethnicity analysis, reasons for non-screening, and awareness of the screening objective were considered for three key categories. The findings indicate that Indian women have the lowest PST test rates and are the least likely to know that cervical cancer is detected.

Moreover, Malay women are less likely to be examined than Chinese women. The explanation for this is the difficulty. Urban women are less likely to be tested because of a lack of time as a basis for a contrast between urban and rural women. Based on these findings, this study indicates that targeted interventions might increase screening rates in Malaysia. This is because the most significant limitation of the study is that it cannot determine that any intervention will increase or cost-effect screening. Next, Abdullah and Su (2010) presented qualitative research on the improved perceived perceptions of the service and the possibility of coordinated cervical screening in Malaysia to improve the Cervical cancer screening programme. This qualitative research was carried out based on 11 primary informant interviews in Malaysia with policymakers and health workers. Based on these findings, it is caused by the lack of women acceptance, weak engagement by medical professionals, the quality of the program, an unsuitable follow-up scheme, limited resources, and other competing needs that the current cervical screening program in Malaysia has faced faults at every stage. It failed to reduce cervical cancer morbidity and death. This study suggests that a new program should concentrate on the policy context, which promises a positive impact on cervical cancer morbidity and mortality to increase screening coverage and lower the burden of cervical cancer.

Meanwhile, Chong et al. (2010) investigated the Human Papillomavirus (HPV) distribution in Malaysia since the new, improved HPV testing and HPV vaccination have been aggressively promoted. This study has been conducted to minimise the cost-effectiveness of HPV, and it focuses on the most populous region in Selangor. The Nested Polymerase Chain Reaction (PCR) extracts the HPV DNA based on 200 cervical swab test samples and women attending obstetrics and gynaecology clinics in several hospitals in Selangor. The result shows that the nested PCR method can detect the HPV DNA highly sensitive even in low-risk patients. This study indicates that early HPV vaccination is required to prevent high cervical cancer incidence because the high HPV prevalence rate in this population has been found. The screening and vaccination program analysis has been further elaborated (Rashwan et al., 2011). This study showed the awareness and prevention level of cervical cancer among Sarawak high school students. To accomplish this analysis, a total of 76 samples from the selected students were used. The samples were selected based on random, multi-stage sampling with different methods. The findings show that $60.5 \%$ of students are aware of cervical cancer and that Chinese people have the highest knowledge. The results also show that the parents $(25.9 \%)$ were the key source of knowledge on cervical cancer. The study revealed that students had poor cervical cancer, in terms of their prevention and acceptance of HPV. Thus, some suggestions, such as educational and awareness programs in schools and community centres, should be made and popular mass media should be utilised to improve cervical cancer, particularly in high schools and public awareness.

Besides, the comparison of screening and vaccination programs between other countries also can be investigated. Hence, an overview study of the cervical cancer screening program between two different countries has been presented (Rashid et al., 2013). The overview studies suggest an organised screening cervical cancer program feasible in Malaysia based on adapting the Australian system. The report shows the percentage age of cervical cancer detected in Stage I (21\%), Stage II (34\%), Stage III (26\%), and Stage IV (19\%). The Chinese ethnic experienced the highest incidence rate compared to Indian and Malay ethnicities. Based on the report, Malaysia is not provided with coordinated population screening. Thus, some changes have been made to the Malaysian environment in a pilot project modelling the screening program in Australia. This initiative aims to enable women to be screened at the highest risk. The key issues are information systems, laboratory monitoring, and quality assurance. Based on previous successful programs established in Australia and New Zealand, efficient tracking data registers and quality assurance systems for labs reporting cervical cytology are the key factors that need to be addressed. Hence, an organised and effective screening program is essential and needs to be established to prevent the insufficient screening of participants. In addition, Gan and Dahlui (2013) studied cervical screening uptake and its predictors among rural women in Malaysia. This study aims to assess rural women and to examine factors relevant to cervical screening in Malaysia. A total of 1000 homes in 5 rural districts in Perak (Malaysia) were selected based on random multi-story sampling. Then, a survey based on the cross-sectional design using structured questionnaires has been used to interview women aged 20 to 64 years. The binomial logistic regression method and univariate and multivariate analyses are utilised to identify the cervical screening predictors. The findings show that 959 women $(48.9 \%)$ had a Pap smear at least once over the past three years. In the population of 40 to 49 years old, other indicators showed that women were more likely than men of age 20 to 29 years to undergo cervical cancer screening. This study found that predictors of cervical cancer uptake have been found for women with children, women with a strong knowledge of cervical symptoms,married women, and those who receive help from their marriages. Based on the findings of this report, the factors related to the use of cervical cancer screening have been helpful. Therefore, the government needs to underline many efforts to increase cervical cancer screening, particularly for rural women.

To increase participation in screening programs, several effective recall methods need to be studied. Therefore, the study about the protocol for the most effective recall 
method in cervical cancer screening programs has been presented (Rashid and Dahlui, 2013). To enable patients who have had previous negative spreading to repeat the pap smear, this study investigated the most successful recall procedures in the cervical cancer screening program in Klang, Malaysia. This study aims to propose two results: the response of patients and the use of a repeat pap spray in a population-based Pap Smear screening program. The inclusion and exclusion requirements were repeated in women aged between 20 to 65 years. There are three recall system groups, where each group consists of 250 subjects, including letters, registered letters, SMS and short messaging services (SMS), and calls. After eight weeks of the callback intervention, both groups were followed up to evaluate their compliance with the callback procedure. The logistic regression analysis from bivariate evaluates the autonomous effect of essential factors in predicting response rates in all four categories from the bivariate analysis. In each intervention, the key result of the research was the rate of response.

On the other hand, Maharajan et al. (2017) presented a survey based on the cross-sectional design using validated questionnaires conducted to interview 270 undergraduate pharmacy students. Based on all respondents, about $81 \%$ knew that the cause of cervical cancer is due to human papillomavirus, while $87.8 \%$ knew this infection is preventable. The results indicated that the overall knowledge and attitude about HPV infection, cervical cancer, prevention, and HPV vaccination were moderately high, with few disagreements about the helpfulness of the HPV vaccine to prevent cervical cancer. Based on this result, several education campaigns can be developed for undergraduate pharmacy students to reduce HPV infections, indirectly reducing cervical cancer incidence in Malaysia.

Likewise, the preliminary study of HPV vaccination has been further investigated by Tusimin et al. (2019) to evaluate the knowledge and attitude in the primary prevention of cervical cancer among University Tunku Abdul Rahman (UTAR) students in Malaysia. Three hundred seventy-four students were recruited to answer the self-administered questionnaires using a convenience sampling method. The results indicated that over half of the respondents $(54.7 \%)$ attained high awareness about HPV vaccines, revealing a negative attitude of approximately $57.5 \%$ to HPV vaccines. Based on this age group, women aged 20 years and under demonstrated strong awareness and a positive attitude of $56.4 \%$ and $55.8 \%$, respectively. At the same time, respondents were $32.7 \%$ less knowledgeable and $37.6 \%$ more positive than the Faculty of Medicine and Health Sciences, which reached more knowledge and positive (67.3\%) attitude (62.4\%) of HPV vaccination. The outcome of these interviewees is from Faculty of Accountancy and Management (FAM). The study concluded that there was a relatively high level of awareness about HPV vaccinations for UTAR students. More recently, Romli et al. (2020) investigated the improvement of the awareness and mindset of women entrepreneurs in Kedah, Malaysia, to achieve the efficacy of health education and the Pap smear test. The simple random sampling method surveyed 250 women from Alor Setar and Sungai Petani districts, of which 125 are women from each community. Variables of interest were derived from self-administered questionnaires for each participant. The interference and control groups exist in two groups. Women were given educational conversation only to the control group and an assessment of results once. Several programs were introduced for the intervention group: informative discussions, demonstration videos, exchanging experiences, pamphlets, and text message reminders. The results were assessed twice for the intervention party. The findings indicate that both the intervention and control groups at assessment stage 1 substantially increased the awareness and attitude to cervical cancer. In the intervention population at assessment stage 2, however, there are no other results achieved. In conclusion, this study found that education was the only way to enhance awareness about cervical cancer and Pap smear in test behaviour and actual tests.

\section{Challenge and Problem}

In Malaysia, the participation of women in cervical cancer screening is low. This is one of the problems that need to be solved. Therefore, Latiff et al. (2015) studied the reliability of the self-sampling device for cervical cancer screening since the data shows that the participation screening in Malaysia is low. This assessment has been implemented to overcome this problem. A total of 258 samples have been conducted in this study based on those who participated in health campaigns from urban and rural. To limit sampling bias, the sample population of this study was randomly divided into two groups. Both samples were analysed based on cytological changes and the identification of HPC DNA. The results demonstrate that self-sampling is well supported by the doctor's samples for HPV detection. It can also be used for cytological abnormalities in Malaysia as a test in HPV screening. However, this research also revealed some limitations, including the poor prevalence of irregular endometrial cells and HPV sample infection as well as lack of cervical biopsy due to financial and ethical problems.

Another problem is the cost to implement the HPV vaccination program. This problem has been studied by Aljunid et al. (2010) by analysing the burden of cervical cancer in Malaysia centred on the possible costs of HPV vaccination and its implications. This study's first goal is to examine the expense of cervical and pre-carcinogenic diseases in Malaysia, including the clinical and economic burden of HPV-induced conditions. The second objective is to predict lasting results for HPV vaccination by using a modelling method based on prevalence. The result shows that almost 4,696 prevalent cervical cancer cases have been registered in a year, while 1,372 precursor cases. It involved a total cost of RM 39.2 million and another RM 12.4 million for indirect expenses. Four thousand one hundred ninetynine cervical cancer cases each year with a bivalent vaccine can be prevented using HPV vaccination compared to 3,804 cases using the quadrivalent vaccine. The cost of the bivalent vaccine is projected at an annual fee of RM 45.4 million, compared to the yearly cost of the quadrivalent vaccine of RM 42.9 million. Based on the findings, the clinical and cost burden of cervical cancer and precancer lesions can be minimised with bivalent vaccines in Malaysia.

Ezat and Aljunid (2010b) further investigated the burden of cost based on the cost-efficacy of HPV vaccination in 
Malaysia to prevent cervical cancer. This study aims to eliminate the costs of chronic management with better screening of HPV and vaccination because this cost significantly impacts the country's health and quality of life. In the six public gynecologic-oncology hospitals, 502 patients were interviewed using several approaches, such as panel discussions of experts to measure care costs by gravity and direct interviews with respondents using cost and SF-36 quality of life (QOL) surveys. The findings are based on comparing Pap smear testing, quadrivalent HPV vaccine, and the combined strategy (screening plus vaccination). This means that vaccination will increase life expectancy with improved quality of life for women. The study also showed that young women's vaccination is a more economical approach toward cervical cancers because it is dubious for Malaysian women to perform long-term detection. Then again, Ezat and Aljunid (2010a) had further investigated the comparison of the cost-effectiveness of HPV vaccines to prevent cervical cancer in Malaysia by using the bivalent vaccine (B.V.) and quadrivalent vaccine (Q.V.). The cost-effectiveness of HPV vaccines has been compared based on three programs: screening via Pap smear, modelling of HPV vaccination (Q.V. and B.V.), and combined strategy (screening plus vaccination). Severity health costs of cervical cancer, genital warts, and vulva vagina cancer have, for example, panel discussions of experts and direct interviews with respondents using costing and SF-35 quality of living questionnaires. The research uses many approaches. The result depends on 502 cervical cancer patients, and it shows that the quadrivalent vaccine is more cost-effective than the bivalent vaccine. Besides, the quadrivalent vaccine based on a combined strategy offers more cost-effectiveness than any method, including pap smear screening at high population coverage.

The result of cervical cancer is a long-term infection with some types of human papillomavirus (HPV). HPV is a common virus that spreads through sex from one person to another. At a certain point in their lives, most sexually active people also have HPV, but only certain women have it. Several studies tried to understand the distribution in multi-ethnic Malaysia of HPV genotype in cervical cancer. The research study in Hamzi et al. (2014) primary purpose was to determine the proportion in our population of genetic variants for human papillomavirus (HPV) in cervical cancer. Two hundred eighty analysed cervical cancer cases in 4 centres in Malaysia used the detection of 12 high-risk HPV genotypes in a real-time polymerase chain reaction (qPCR. In all ethnic groups, HPV 16 and 18 genotypes were the most prevalent. Researchers have found a significantly higher proportion of HPV 16 disease among Chinese (75.9\%) compared with Malay (63.7\%) and Indian (52.0\%). Findings proved that in other Asian countries like China, Hong Kong, Taiwan, Japan, Korea, Thailand, and Indonesia, HPV genotype distribution in Malaysia is very similar. Presenting HPV 16 and 18 prophylactic vaccines in a large proportion of Malaysian women will prevent cervical cancer. To ensure more comprehensive vaccine coverage, the nextgeneration HPV vaccine should include HPV 58, 52, and 33 genotypes. Razak et al. (2013b) research aimed to evaluate the five-year survival of Hospital Universiti Sains Malaysiatreated cervical cancer patients.
Five years' survival in Phases I, II, and III-IV, respectively, yielded $54.7 \%, 40.8 \%$, and $18.4 \%$. The patients with late-stage IV diagnosis Have slightly higher survival rate of 33\%. Data shows that HUSM treated cervical cancer patients' prognoses depending on the detection level and primary treatment they received. The probability of survival was calculated using Kaplan Meier and comparing survival distribution among groups with the log-rank test. The average mortality of 5 years was $39.7 \%$ for 40.8 months medium. The lowest survival rate was seen in patients hospitalised at the latest stages (III-IV). In short, in this study, the survival of patients with cervical cancer for five years was low, and the overall survival of those who underwent operation were higher than those without primary treatment.

Next, the research was to recognise cervical cancer screening activities and factors influencing the screening status of African immigrants attending selected churches in Klang Valley, Malaysia (Nwabichie et al., 2018). A crosssectional survey of 320 iteratively chosen participants between the ages of 18 and 69 was performed in three separate churches with a high percentage of African respondents. To ensure precise interpretation, the questionnaire was prepared and self-explained in English since English is the main spoken language of the sample population. Three analysis stages were performed using SPSS 21, including data analysis, chi-square, and multiple regression analysis. The data collected was $98.2 \%$, where the bulk (68.1\%) of participants were 31-50 years of age and married. Marital status, awareness, potential obstacles, and a daily healthcare provider presence were predictive factors. The results found that the initiation of cervical cancer screening by African women was very poor. According to the authors, unique awareness-raising projects to improve absorption should be planned and enforced by the responsible authorities. In the final point, there was a low average incidence of cervical cancer screening among women. Marital status, daily HCP, inherent obstacles, and awareness have been the indicators of Pap smear test uptake identified in the report. Therefore, preventive trials and services are required to improve the screening uptake of this research group.

Besides, the analysis assessed the efficacy of the Pap smear test strategy among trained, employed women in Malaysia. About four hundred and three teachers who have never or occasionally taken a Pap exam from 40 public secondary schools in Kuala Lumpur have been appointed to a randomised cluster trial. The intervention program was engaged in the workplace's cervical screening campaign (Abdullah et al., 2013). The control group obtained standard treatment from the current cervical screening programme. The percentage age of women involved in the Pap test was slightly higher in the experiment than in the control group. Workplace health promotion initiatives significantly raise the incidence of cervical dating among qualified women in middle-income countries. Policy leaders and health care professionals in these countries should incorporate those measures to reduce the burden of cervical cancer. In the final result, the coordinated call-recall cervical cancer screening programme in Malaysia can significantly reduce the reliance on cervical cancer incidence and mortality. Worksite cervical screening programmes (with both an 
acceptance and a follow-up element) can provide an alternative means of increasing the prevalence of Pap test in the current opportunistic cervical screening procedure. This alternative work-based health promotion stratum should be valued by policymakers and health care professionals in middle-income countries as a positive strategy to reduce the long-standing challenge of cervical cancer in Malaysia.

Furthermore, a study about the Survival Rates of Cervical Cancer Patients in Malaysia was made. Muhamad et al. (2015) stated that Malays in conjunction to Indians (69.5\%) and Chinese $(73.8 \%)$ has the lowest survival rate of $59.2 \%$. This study showed an overall recovery time of 65.8 months for cervical cancer with a survival rate of 71.1 per cent over five years. Age and race classes continue to be essential drivers of survival. The research took place from 1st January 2000 to 31st December 2005 on two different bases, the Malaysian National Cancer Registry (MNCR) and the National Hygiene Informatics Centre (NHIC). To determine the average survival rate and the median time, Kaplan Meier studies were carried out. The log-rank test compared the disparities of survival between different ethnic and age groups.

Furthermore, Malaysia's overall survival rate for five years is very high for cervical cancer patients. Both the age and ethnic classes also determine the survival rate. The Cancer Registry is recommended for more information on other lifestyle variables to be checked. More details on other lifestyle factors such as the stage of infection, type of cervical cancer, and the comprehensiveness of the case list are recommended for the cancer registry to be updated. In 2010, Al-Naggar et al. (2010) conducted a research on two hundred eighty-seven female from tertiary students based in Selangor, Malaysia, via a a cross-sectional configuration. Using SPSS version 13, the data was evaluated. Most participants were well aware of cervical cancer risk factors.

In summary, the researchers claimed that the Pap Smear test was the most common barrier to cervical cancer screening. Participants did not favour the companion as the least common impediment. However, the youth seems to have minimal Pap testing experience. Therefore, all university students must be aware of cervical cancer screening if the inclusion of reproductive health subjects is justified.

\section{Discussion}

Cervical cancer diagnosed earlier on is not only durable but is also largely preventable. The results for patients with cervical cancer should be better than before via routine screening tests, specifically the Pap smear and the HPV DNA test, and HPV (human papillomavirus) vaccination. This is to raise awareness among women, girls, and men about the importance of screening with a comprehensive programme. The Ministry of Health of Malaysia $(\mathrm{MoH})$ introduced Pap smear screening in 1969. Moreover, the $\mathrm{MoH}$ and the Ministry of Women, Family, and Community Development's National Population and Family Development Board provided services for Pap Smear screening. The second National Health \& Morbidity Survey (NHMS II) reported in 1996 that only $26 \%$ of qualifying women had ever used Pap smears for cervical cancer, which rose to $43.7 \%$ in 2006 (NHMS III). The NHMS 2011 survey showed that in the past
12 months, only $12.8 \%$ of qualifying women had a Pap smear test completed. The $\mathrm{MoH}$ aims to increase the National Pap Smear Screening Program's coverage, efficacy, and quality. This entails a growing public understanding of Pap smear screening for cervical cancer and enhancing Pap smear tests' effectiveness and quality. One of the screening technologies that has superior advantages over traditional approaches is liquid-based cytology. Population-based screening coverage, particularly for women over 30 years of age, should be increased and made available to every qualified woman in the nation. The WHO has suggested that cervical cancer must be tested at least once or more by the proportion of women between 30-49 years of age and under national strategies and policies for lower and higher age groups. As a blueprint for primary prevention, the Human Papillomavirus (HPV) immunisation program has also been introduced. However, the cervical screening campaign should be maintained, as only $71 \%$ of cervical cancer are expected to be avoided by HPV vaccination. HPV DNA testing as primary screening or as co-testing is the potential path. Efforts must raise women's awareness of cervical cancer and preventive health-seeking behaviour to reduce cervical cancer incidence and mortality. Efforts to organise an effective campaign to prevent cervical cancer involve the government, health agencies, physicians, pathologists, medical professionals, the media, and the public to cooperate and fully commit themselves. This initiative must be supported by sufficient financial support, infrastructure and equipment improvements, as well as increased medical staff training. Due to many factors, such as population growth and ageing, cancer incidence has risen. It is also linked to economic and social development in the form of rapidly growing economies, especially cancer caused by poverty-related and lifestyle-related infections, mimicking cancer in developed countries.

One way of solving the incidence rate of cervical cancer is by prevention. The first way to prevent cervical cancer rate is by using the screening method. In Malaysia, two convenient types of cervical cancer screening tests are the Pap Smear test and HPV test. Early diagnosis is essential to appropriately diagnose and prevent the cell evicted by precancerous and cancerous infections. Meanwhile, the second one identifies HPV-linked conditions, which could increase the risk of cancer.

In most cases, the infectious disease resolves independently and does not result in precancerous cell changes. However, a persistent infection by a particular HPV type could result in abnormal cervical cells. Whether these abnormalities (precancerous or high-grade carcinomas) are left untreated for an extended time, this infection may develop into cervical cancer (Tsikouras et al., 2016). The second way to prevent cervical cancer in Malaysia is by receiving the HPV vaccine injection. This research has shown that the types of HPV that cause most cervical cancers can be prevented using these vaccines (Rajiah et al., 2017). A vaccination that protects against HPV lasts for about 6 to 8 years. However, the protection's effectiveness is unknown. Cervical cancer can be prevented with the currently licenced HPV vaccines, which prevent infection by various HPV types. To maximise vaccines' effectiveness, they should be administered to an individual before exposure to HPV (Patra and Panda, 2010). Although vaccines cannot be used to treat cervical cancer or 
HPV infection, they can still be quite helpful when given before people become infected (World Health Organization, 2016).

In addition, this is another preventative measure against cervical cancer in Malaysia. Cigarette smoking avoidance can reduce the chances of getting cervical cancer. The HPV infection from the body is more likely to turn into cancer if someone smokes (Fonseca-Moutinho, 2011). Human papillomavirus (HPV) infection is frequently found in people with cervical cancer. Since HPV is spread via unprotected sex, protected intercourse may help reduce the risk of contracting the infection (Maree and Wright, 2007). However, this preventative measure is the least likely to occur because the age of Malaysian women involved in this problem is the lowest since most of them are Muslims, where this unsafe habit is prohibited.

On the other hand, some initiatives to minimise the risk of cervical cancer must be implemented, for example, governments collaborating with key partners such as the commercial sector and civil society. The public sector can use the commercial sector's efficiency management to increase workflow and output. Meanwhile, general knowledge of cervical cancer prevention and control can be raised if civil society supports accessible, inexpensive, and good health in their communities, particularly among those at high risk of the illness. Survivors of cervical cancer can also act as campaigners, educating women and girls about the importance of immunisation, screening, and treatment, as well as combating stigma. Primary, secondary, and tertiary preventions are the three types of prevention used to reduce the incidence rate. In primary prevention, HPV vaccination is targeted at girls aged between 9 to 14 . Primary prevention content includes health information, tobacco use warnings, and sexuality education suited to age and culture. Women under the age of 30 are screened with a highperformance test equivalent to or better than the HPV test for secondary prevention. Finally, tertiary prevention for all women includes surgery, radiation, chemotherapy, and palliative care to treat invasive cancer at any age.

Since cervical cancer is the third-ranking in Malaysia as the leading cause of death, several measures and approaches were conducted to improve the understanding of HPV and cervical cancer. For instance, a review of HPV and cervical cancer knowledge among Malaysian residents has been organised by Nahrawi et al. (2020). This review is measured based on the knowledge before and after the implementation of the HPV vaccine program. The approach was applied in various groups such as universities, schools, and women in Malaysia. Tab. 5 shows the summary of issues before and after implementing the national HPV vaccine program on HPV and cervical cancer among Malaysian residents.

In addition, the best preventive measures to prevent cervical cancer are HPV vaccination and routine Pap smear testing. This knowledge should be exposed starting from secondary school. Therefore, the knowledge gained from the secondary school is essential information and the benchmark to improve the understanding of HPV and cervical cancer in Malaysia. Rashwan et al. (2011) conducted a study about the knowledge of cervical cancer and acceptance of HPV vaccination among secondary school students in Sarawak, Malaysia. The results show that the students had a poor knowledge level of cervical cancer,

\section{TABLE 5}

Summary of issues before and after implementing the national HPV vaccine program on HPV and cervical cancer among Malaysian residents

\begin{tabular}{|c|c|c|}
\hline Issues & Before & After \\
\hline $\begin{array}{l}\text { Awareness of } \\
\text { HPV and } \\
\text { cervical } \\
\text { cancer }\end{array}$ & Low & Low \\
\hline $\begin{array}{l}\text { Knowledge of } \\
\text { HPV and } \\
\text { cervical } \\
\text { cancer }\end{array}$ & $\begin{array}{l}\text { Less than half of the } \\
\text { respondent had heard } \\
\text { about HPV, HPV } \\
\text { vaccine and Pap smear } \\
\text { test }\end{array}$ & $\begin{array}{l}\text { Most of the respondent } \\
\text { know about HPV, HPV } \\
\text { vaccine and cervical } \\
\text { screening test }\end{array}$ \\
\hline $\begin{array}{l}\text { Attitude on } \\
\text { HPV } \\
\text { vaccination }\end{array}$ & $\begin{array}{l}\text { Positive attitude } \\
\text { towards vaccination. } \\
\text { The parents will } \\
\text { vaccinate their children } \\
\text { if the vaccine is free } \\
\text { because the vaccine is } \\
\text { expensive }\end{array}$ & $\begin{array}{l}\text { Positive attitude } \\
\text { towards vaccination }\end{array}$ \\
\hline
\end{tabular}

prevention, and HPV vaccination acceptance. Based on this benchmark, more efforts regarding the vaccination program should improve the public's cervical cancer knowledge and awareness, especially for secondary school students. Other approaches to improving the understanding of HPV and cervical cancer are evaluating and ascertaining the current knowledge, perception, level of awareness, and attitudes toward cervical cancer among women in Malaysia (Seng et al., 2018).

Furthermore, the measures and approaches to improve the understanding of HPV and cervical cancer in Malaysia are also necessary. Based on a study, more information on HPV, HPV vaccine, and cervical cancer is created by implementing the national HPV vaccination programme (Nahrawi et al., 2020). The study's findings were massively positive. Fortunately, individuals show that many women in Malaysia and other countries have limited awareness regarding HPV and cervical cancer. To raise awareness about cervical cancer, these measures shall be taken (Romli et al., 2019). HPV vaccination and Pap Smears, when implemented in tandem, are cost-effective at reducing the risk of cervical cancer. It is required that educational programmes devised by those who handle health policy be used by the general public to enhance understanding and reduce illness.

Nevertheless, detection and prevention strategies are essential for reducing cervical cancer variances. Through community engagement, disparities in cervical cancer disease are whittled down among high-risk individuals (Staples et al., 2018). This research indicates that an educational intervention to raise awareness about HPV and cervical cancer had a satisfactory outcome (Staples et al., 2018; Santos et al., 2020).

\section{Conclusion}

Cancer in Malaysia has a massive effect on the population, where the Malaysian health system is a leading cause of 
premature death and disease. The Ministry of Health and other relevant agencies' main goals are to minimise cancer incidence while maintaining the highest quality of treatment and results for those who encounter the disease. These data enable the health system to identify opportunities for strengthening cancer prevention initiatives, enhance early detection through screening programs, as well as maximise national and local level care services and clinical trials. Early detection, screening, and diagnosis have dramatically increased patients' survival and quality of life rates, significantly reducing cancer care cost and difficulty. However, to substantially reduce the personal and financial burden, obstacles to achieving higher rates of early detection of cancer need to be tackled now at the individual, health system, and government level. One important progress will be the re-initiation of interagency meetings to facilitate planning and monitoring of the Cancer Control Programme. Thus, agencies like the universities, Health Promotion Board, and NGOs can be more effectively coordinated and united to improve Cancer Control in Malaysia. The strategy for this revision is to consolidate the progress achieved thus far and embark on affordable activities, especially enhancing public awareness, screening coverage, palliative care, developing psycho-oncology, value-based medicine, and patient navigation.

The National Cancer Registry (NCR) has led the reporting of the Malaysian National Cancer Registry, which provides nationwide cancer data and information to all related professionals, policymakers, primary health care networks, and participating private hospitals, based on data collected through 13 states and two federal territories of cancer registries. These data help the health system discover possibilities to improve cancer prevention activities, increase early diagnosis through screening programmes, as well as optimise treatment services and clinical trials nationally and locally. Patients' survival rates and quality of life have been shown to improve dramatically with early detection, screening, and diagnosis, as well as the expense and complexity of cancer therapy. However, to substantially reduce the human and financial burden of cancer worldwide, hurdles to reaching better early cancer detection rates must be tackled today at the individual, health system, and political levels. When designing national cancer control programmes, all agencies must work together to create ideal conditions when developing cancer control strategies. This prerequisite comprises political will and pledges, coordination among major national organisations, and the expense of planned cancer mortality reduction programmes. This report was a watershed moment in the country's efforts to improve cancer prevention and management.

The Ministry of Health Malaysia gathered together prominent oncologists, clinicians, public health specialists, pathologists, radiologists, academia, scientists, researchers, and policymakers to review and initiate updates for the national Cancer Control Blueprint (NCCB) in 2008-2015. They proposed the National Strategic Plan for Cancer Control Programme (NSPCCP) (2016-2020) to replace the NCCB (2008-2015). The NSPCCP's objective is similar to the NCCB's objective to lessen the negative effects of cancer by lowering morbidity and mortality as well as improving the quality of life for cancer patients and their families. To accomplish this, the NSPCCP has designated nine (9) areas of focus, each with its own set of objectives, targets, and strategic action plans for implementing complete cancer care across the country by 2020. The NSPCCP used a holistic approach to cancer care and management, including primary prevention, screening, early detection, diagnosis, treatment, rehabilitation, palliative care, traditional and complementary medicine (T\&CM), as well as research.

To address cancer burden and management issues in the country, the NSPCCP calls for the support and commitment of all stakeholders, the strengthening of existing networks, and better collaboration between public and private sector agencies, particularly private cancer centres, professional bodies, and NGOs. To ensure the successful execution of the NSPCCP (2016-2020), it is critical to monitor and evaluate the various initiatives regularly. To address the country's cancer burden and management issues, the NSPCCP calls for the support and engagement of all stakeholders, strengthening existing networks, and closer coordination between public and private sector agencies, including private cancer centres, professional bodies, and non-governmental organisations. Continuous monitoring and assessing the various activities are critical for successfully executing the NSPCCP (2016-2020). From a comprehensive perspective, the National Strategic Plan for Cancer Control Program (NSPCCP) (2016-2020) addresses cancer care and management through primary prevention, screening, early detection, diagnosis, treatment, recovery, palliative care, conventional and alternative medicine, as well as research. It is a series of contributions from different fields involved in cancer prevention, government and non-government organisations, and the Ministry of Health. We know that the incidence and impact of cancer can be substantially reduced with better prevention, early detection, and treatment.

However, for optimal cancer control and care in the country, there is a need for better integration, collaboration, and coordination across government and private sectors as well as non-governmental and professional organisations. Generally, one-third of cancers are preventable. Another third can be effectively treated if given early detection and treatment, while the quality of life for the remaining third with more advanced disease can be improved with pain relief and palliative care. The National Strategic Plan for Cancer Control Programme (NSPCCP) 2016-2020 addresses cancer care and management from a holistic viewpoint spanning primary prevention, screening, early detection, diagnosis, treatment, rehabilitation, palliative care, as well as traditional and non-traditional complementary medicine and research. It collects inputs from various disciplines, government, and non-government agencies involved in cancer control, with the Ministry of Health as the main contributor. It spells out detailed activities that relevant agencies can carry out. The activities are intended to operationalise the seven strategies outlined by the WHO.

Author Contribution: The authors confirm contribution to the paper as follows: study flow and design: Wan Azani Mustafa, Y.; data collection and anaylsis: Afiqah Halim; analysis and interpretation of results: Mohd Wafi Nasrudin; draft manuscript preparation: Khairul Shakir Ab Rahman. 
All authors reviewed the results and approved the final version of the manuscript.

Funding Statement: This work was supported by funding by the Ministry of Higher Education Malaysia under the Fundamental Research Grant Scheme (FRGS/1/2018/ SKK13/UNIMAP/02/1).

Conflicts of Interest: The authors declare that they have no conflicts of interest to report regarding the present study.

\section{References}

Abdullah F, Rorke MO, Murray L, Su TT (2013). Evaluation of a worksite cervical screening initiative to increase pap smear uptake in Malaysia: A cluster randomized controlled trial. BioMed Research International 2013.

Abdullah F, Su TT (2010). Enhancement of the cervical cancer screening program in malaysia: A qualitative study. Asian Pacific Journal of Cancer Prevention 11: 1359-1366.

Adilah A (2018). Cancer Fourth Biggest Killer in Malaysia. Kuala Lumpur: Malay Mail.

Aljunid S, Zafar A, Saperi S, Amrizal M (2010). Burden of disease associated with cervical cancer in Malaysia and potential costs and consequences of HPV vaccination. Asian Pacific Journal of Cancer Prevention 11: 1551-1559.

Al-Naggar RA, Low WY, Isa ZM (2010). Knowledge and barriers towards cervical cancer screening among young women in Malaysia. Asian Pacific Journal of Cancer Prevention 11: 867-873.

Chong PP, Asyikin N, Rusinahayati M, Halimatun S, Rozita R et al. (2010). High prevalence of human papillomavirus DNA detected in cervical swabs from women in Southern Selangor. Malaysia Asian Pacific Journal of Cancer Prevention 11: 1645-1651.

Dunn RA, Tan AKG (2010). Cervical cancer screening in Malaysia: Are targeted interventions necessary? Social Science \& Medicine 71: 1089-1093. DOI 10.1016/j.socscimed.2010.06.016.

Ezat SWP, Aljunid S (2010). Comparative cost-effectiveness of HPV vaccines in the prevention of cervical cancer in Malaysia. Asian Pacific Journal of Cancer Prevention 11: 943-951.

Faten Nurjihan T, Abdul Rahman T, Rahman NAA, Mohd Shafri MA, Haque M (2019). The knowledge, attitude, and practice regarding pap smear, cervical cancer, and human papillomavirus among women attending a mother and child health clinic in Kuantan, Malaysia. Indian Journal of Medical and Paediatric Oncology 40: 193-200. DOI 10.4103/ijmpo.ijmpo_199_17.

Fonseca-Moutinho JA (2011). Smoking and cervical cancer. ISRN Obstetrics and Gynecology 2011: 1-6. DOI 10.5402/2011/847684.

Gan DEH, Dahlui M (2013). Cervical screening uptake and its predictors among rural women in Malaysia. Singapore Medical Journal 54: 163-168. DOI 10.11622/smedj.2013047.

Hamzi S, Raub A, Isa N, Zailani HA, Omar B et al. (2014). Distribution of HPV genotypes in cervical cancer in multiethnic Malaysia. Asian Pacific Journal of Cancer Prevention 15: 651-656.

Khoo CL, Teoh S, Rashid AK, Zakaria UU, Mansor S et al. (2011). Awareness of cervical cancer and HPV vaccination and its affordability among rural folks in penang Malaysia. Asian Pacific Journal of Cancer Prevention 12: 1429-1433.

Kokol P, Vošner HB (2018). Discrepancies among Scopus, Web of Science, and PubMed coverage of funding information in medical journal articles. Journal of the Medical Library Association 106: 81-86. DOI 10.5195/JMLA.2018.181.

Latiff LA, Rahman SA, Wee WY, Dashti S, Andi Asri AA et al. (2015). Assessment of the reliability of a novel self-sampling device for performing cervical sampling in Malaysia. Asian Pacific Journal of Cancer Prevention 16: 559-564. DOI 10.7314/ APJCP.2015.16.2.559.

Maharajan MK, Rajiah K, Num KSF, Yong NJ (2015). Knowledge of human papillomavirus infection, cervical cancer and willingness to pay for cervical cancer vaccination among ethnically diverse medical students in Malaysia. Asian Pacific Journal of Cancer Prevention 16: 5733-5739. DOI 10.7314/APJCP.2015.16.14.5733.

Maharajan MK, Rajiah K, Sze Fang KN, Lui LY (2017). Cervical cancer prevention in Malaysia: Knowledge and attitude of undergraduate pharmacy students towards human papillomavirus infection, Screening and Vaccination in Malaysia. Journal of Cancer Education 32: 166-174.

Malaysia of Health National Cancer Registry (2011). Malaysia Cancer Statistics-Data and Figure 2007. National Cancer Registry Report.

Malhi FS, Sugathan S, Rajan KD, Singh DSB, Saadi H et al. (2018). Knowledge on cervical cancer prevention and attitude towards pap smear and HPV vaccination among women attending a health clinic in IPOH. Malaysia Journal of Global Pharma Technology 10: 123-127.

Maree JE, Wright SC (2007). Sexual and menstrual practices: Risks for cervix cancer. Health SA Gesondheid 12: 55-65.

Ministry of Health Malaysia (2007). National cancer registry report. Cancer 42-43.

Ministry of Health Malaysia (2011). National Cancer Registry Report, Malaysia Cancer Statistics 2007. Ministry of Health Malaysia, Kuala Lumpur.

Ministry of Health Malaysia (2017). National Strategic Plan for Cancer Control Programme 2016-2020. Kuala Lumpur.

Moher D, Liberati A, Tetzlaff J, Altman D (2009). Preferred reporting items for systematic reviews and metaAnalyses: The PRISMA statement. PLoS Medicine 6: 1-6.

Muhamad NA, Kamaluddin MA, Adon MY, Noh MA, Bakhtiar MF et al. (2015). Survival rates of cervical cancer patients in Malaysia. Asian Pacific Journal of Cancer Prevention 16: 3067-3072.

Nahrawi N, Mustafa WA, Kanafiah SNAM (2020). Knowledge of Human Papillomavirus (HPV) and cervical cancer among Malaysia Residents : A review. Sains Malaysiana 49: 1687-1695.

National Cancer Institute (2019). Malaysia National Cancer Registry Report (MNCRR) 2012-2016. National Cancer Registry, Ministry of Health Malaysia. Kuala Lumpur.

Nwabichie CC, Manaf RA, Ismail SB (2018). Factors affecting uptake of cervical cancer screening among African women in Klang Valley. Malaysia 19: 825-831.

Omar Z, Ali Z, Tamin N (2010). Malaysian Cancer Statistics-Data and Figures Peninsular Malaysia 2006. National Cancer Registry, Ministry of Health Malaysia. Kuala Lumpur.

Osman MT, Al-Naggar RA, Taha BI (2013). Knowledge and awareness of cervical cancer screening among Iraqi immigrant women living in Malaysia. World Journal of Medical Sciences 8: 123-129.

Othman NH, Rebolj M (2009). Challenges to cervical screening in a developing country: The case of Malaysia. Asian Pacific Journal of Cancer Prevention : APJCP 10: 747-752.

Patra S, Panda D (2010). Cervical cancer screening in developing countries. Indian Journal of Cancer 47: 344-345. DOI 10.4103/0019-509X.64704. 
Puteh SEW, Ng P, Aljunid SM (2008). Economic burden of cervical cancer in Malaysia. Medical Journal of Indonesia 17: 272-280. DOI 10.13181/mji.v17i4.330.

Rajiah K, Maharajan MK, Fang Num KS, How Koh RC (2017). Knowledge about human papillomavirus and cervical cancer: Predictors of HPV vaccination among dental students. Asian Pacific Journal of Cancer Prevention 18: 1573-1579.

Rashid RMA, Dahlui M (2013). Study protocol for the most effective recall method in a cervical cancer screening program in klang, Malaysia. Asian Pacific Journal of Cancer Prevention 14: 5867-5870. DOI 10.7314/APJCP.2013.14.10.5867.

Rashid RMA, Dahlui M, Mohamed M, Gertig D (2013). Adapting the Australian system: Is an organised screening program feasible in Malaysia?-An overview of the cervical cancer screening in both countries. Asian Pacific Journal of Cancer Prevention 14: 2141-2146. DOI 10.7314/APJCP.2013.14.3.2141.

Rashwan H, Lubis SH, Ni KA (2011). Knowledge of cervical cancer and acceptance of hpv vaccination among secondary school students in Sarawak. Malaysia Asian Pacific Journal of Cancer Prevention 12: 1837-1841.

Razak NA, Khattak MN, Naing NN, Zaki NM, Zubairi YZ (2013). Survival analysis of cervical cancer patients treated in hospital universiti sains Malaysia. International Medical Journal 20: 707-710.

Romli R, Shahabudin S, Saddki N, Mokhtar N (2019). Cervical cancer and pap smear screening: Knowledge, attitude and practice among working women in northern state of Malaysia. Medical Journal of Malaysia 74: 8-14.

Romli R, Shahabudin S, Saddki N, Mokhtar N (2020). Effectiveness of a health education program to improve knowledge and attitude towards cervical cancer and pap smear: A controlled community trial in Malaysia. Asian Pacific Journal of Cancer Prevention 21: 853-859. DOI 10.31557/ APJCP.2020.21.3.853.

Santos ACDS, Silva NNT, Carneiro CM, Coura-Vital W, Lima AA (2020). Knowledge about cervical cancer and HPV immunization dropout rate among Brazilian adolescent girls and their guardians. BMC Public Health 20: 394. DOI 10.1186/s12889-020-8410-9.

Schmidt CM, Cox R, Fial AV, Hartman TL, Magee ML (2016). Gaps in affiliation indexing in Scopus and PubMed. Journal of the
Medical Library Association 104: 138-142. DOI 10.3163/ 1536-5050.104.2.008.

Seng LM, Rosman AN, Khan A, Haris NM, Mustapha NAS et al. (2018). Awareness of cervical cancer among women in Malaysia. International Journal of Health Sciences 12: $42-48$.

Sheikh SA, Simbak N Bin, Ismail SB, Rahman NIA, Rebuan HMA et al. (2015). HPV vaccine among men and women attending for HPV vaccination in Terengganu. Malaysia 31: 242-246.

Staples JN, Wong MS, Rimel BJ (2018). An educational intervention to improve human papilloma virus (HPV) and cervical cancer knowledge among African American college students. Gynecologic Oncology 149: 101-105. DOI 10.1016/ j.ygyno.2017.10.015.

Tsikouras P, Zervoudis S, Manav B, Tomara E, Iatrakis G et al. (2016). Cervical cancer: Screening, diagnosis and staging. Journal of BUON 21: 320-325.

Tusimin M, Yee C Lo, Razak NZSA, Zainol MI, Minhat HS et al. (2019). Sociodemographic determinants of knowledge and attitude in the primary prevention of cervical cancer among University Tunku Abdul Rahman (UTAR) students in Malaysia: Preliminary study of HPV vaccination. BMC Public Health 19: 1-6.

WHO (2019). All Cancer. International Agency for Research on Cancer. France.

WHO (2020). World Cancer Report 2020. World Health Organization. Geneva, Switzerland.

World Health Organization (2016). Guide to introducing HPV vaccine into national immunization programmes. World Health Organization 104.

Yeung AWK (2019). Comparison between Scopus, Web of Science, Pubmed and publishers for mislabelled review papers. Current Science 116: 1909.

Zainal Ariffin O, Nor Saleha IT (2011). National cancer registry report Malaysia cancer statistics-data and figure 2007. National Cancer Registry Report Malaysia Cancer StatisticsData and Figure 2007. Kuala Lumpur.

Zaridah S (2014). A review of cervical cancer research in Malaysia. Medical Journal of Malaysia 69: 33-41.

Zaridah S, Ukm MOG (2014). A review of cervical cancer research in Malaysia. Medical Journal of Malaysia 69: 33-41. 